issue, it reminds us that the history of the interrelationship between workers and labor movements on one hand and a whole range of religious impulses on the other in nineteenth century France remains to be explored.

Finally, it might be useful to list several other papers dealing with French social and economic history that I feel might be of some interest to our readers.

"Identifying Bourgeois Elites: Reims and St. Etienne under the July Monarchy and Second Empire," David Gordon (U. of North Carolina)

"The Elite of France on the Eve of Industrialization," Thomas Beck (SUNY Albany)

"Professionalization and Modernization: the Case of the French Deputy, 1876-1940,' James Q. Graham, Jr. (Bowling Green U.)

"Professionalization and Gender: Secular Elementary School Teachers in the Belle Epoque," Peter Meyers (North Carolina A\&T State U)

"Education and the Industrial World: French Technical Instruction and the Recruitment of Industrial Elites Under the Third Republic, 1870-1914,' C. Rod Day (Simon Fraser U.)

"Educational Growth, Mobility, and Modernism in Mid-Nineteenth Century France," Patrick Harrigan (U. of Waterloo)

"The Vendee Revisited: New Evidence on the Civil War," Alison Patrick (U. of Melbourne)

"Popular Counterrevolution in the West," Donald Sutherland (Brock U.) and Timothy LeGoff (York U.)

"Learned Societies and Polite Amusement, 1815-1914," Robert Fox (U. of Lancaster/Princeton U.)

Christopher S. Johnson

Wayne State University

\title{
SECOND INTERNATIONAL CONGRESS OF NORTH AMERICAN HISTORY, MILAN
}

In June 1979, Italian historians of North America hosted a Congress in Milan on radicalism in the United States from the Revolution to the Cold War. It was an impressive affair. Over a hundred scholars gathered from almost a dozen countries for three and a half days of continuous discussion. Even before we arrived at the da Vinci museum, where the Congress was held, we saw, wedged among the wall posters for the European parliamentary elections, posters for the Congress inviting the public to a concert of American labor songs. The daily press and the radio reported on the proceedings. 
For the small band of veteran Americanists in Italy, the Congress was an achievement they believe will bring their discipline recognition and new opportunities. As the pre-eminent pioneer in the field, Giorgio Spini, put it, "we used to be seen as guerilla fighters. Now we have belligerent status."

It is significant, and not a little curious, that so many of the Italian historians should be interested in the radical side of the United States. The explanation, in part, is the double ostracism American history has suffered from the intellectual establishment. For intellectuals linked to the Communist Party, the United States hardly seemed worthy of sympathetic study, an attitude fostered by the Cold Warrish approach of American cultural affairs missions and the denial of entry to Communist visitors. For opposite reasons, conservative Catholics spurned the United States as a bastion of liberalism. Thus by virtue of neglect, the field was open to the younger generation close to the extra-parliamentary left, who began to examine the United States as it burst forth with radical enthusiasm at the end of the $1960 \mathrm{~s}$. Their work provided the largest number of papers at the Congress, although other viewpoints were well represented, and credit for a varied and wide-ranging program must go to the organizing committee, including the president Loretta Valtz Mannucci, and the secretary Gian Giacomo Migone. That arrangements went so well was also owing to the staff of assistants so ably headed by Luisa Cetti.

To chart the course of American radicalism is to follow internal changes in the relation between civil and political society and external changes in the relation between the United States and the rest of the world. At its inception and for decades thereafter, the United States was the image of the future for many Western radicals. It was anti-authoritarian in both public and private life, opposed to aristocratic rule and dynastic wars, and on the side of enlightenment and progress. A number of papers and comments touched on this theme of early America as a radical society. Special attention was paid to artisans in the Revolutionary era, who imparted a tenacious tradition of republicanism to the nineteenth century laboring classes, and the question was raised whether the very success of egalitarian ideas among the majority of small farmers and artisans imprisoned American radicalism within a bourgeois framework. While the emphasis on shared values among otherwise contesting groups resembles a theme of the old consensus school, participants insisted on the transforming and even revolutionary force of republicanism in the international context of that period.

By the end of the nineteenth century, however, America had ceased to represent the future. In its hostile reaction to the Paris Commune, in its lack of such social legislation as Germany had enacted, and in its stubborn refusal to give itself up to socialism, the United States appeared politically retrograde to most progressives. Internally, a generation of fierce class conflict after the Civil War had driven a deep wedge between the republicanism of the propertied and the outlook of the propertyless, with the result, as several participants noted, that political radicalism (socialism) was isolated even from large segments of the working class. What had happened? Was American radicalism really chained to property? 
Apart from a richly suggestive paper on Wisconsin socialism and skilled workers, the papers tended to bypass socialist parties to focus on strike action and the Industrial Workers of the World. The I. W. W. is a favorite subject in Italy, and the Congress marked the fruition of several years work on direct action, the concept of One Big Union, and revolutionary unionism. Along with other material on the great strikes of the late 19th century and the mass insurgency leading to the big strike wave of 1919-22, the implication left at the end of the second day's proceedings was that radicalism was more likely to originate in the experiences of civil society-the workplace, ethnic and community life, personal relations-than in the institutions of political society, including both parties and trade union bureaucracies.

Picking up this theme, some of the contributions on the third day distinguished between "political radicalism" and "social radicalism" and pointed toward the questions and methods of social history as the next step in the progress of the discipline. If the pitfall of de-politicizing the subject can be avoided, then this approach has some more contributions to make in explaining why people who love change so much, as Tocqueville put it, should have come to fear revolution. If these results can be linked up with the analysis of counter-revolution in American foreign policy, so much the better.

A crucial moment for consideration would be the onset of the Cold War, and what happened to the Communist Party at that time. In fact, the most spirited and engaging debate of the entire proceeding occurred over the American Communist Party, an irony in light of the virtual absence of its Italian counterpart. Did the CP fail because of domestic reasons (such as the war-time no-strike pledge) or international reasons (its unswerving adherence to Soviet foreign policy)? Or did it fail at all? Several speakers argued variously with some vehemence that the Communists emerged from World War II as the predominant leftwing influence in the labor movement, that their decline was the result of state repression, and that their radicalism persisted while rivals folded their tents to join the camp of Cold War liberals. The fate of the Communist Party is a measure of how far America and the rest of the world have come since the eighteenth century age of revolution.

Although the mainstream of discussion centered on labor radicalism, other subjects were also broached-feminism, abolitionism, agrarianism, nativism, and cultural aspects of radicalism in the twentieth contury. A published edition of the proceedings in Italian and English is promised. Given the magnitude of the undertaking, it seems unlikely such an event on this theme will occur for a long time to come.

\author{
Alan Dawley \\ Langhorne, Pa.
}




\section{Labour/Le Travailleur}

Contents of Volume 4, 1979

H.C. Pentland-The Canadian Industrial Relations System: Some Formative Factors

John Battye-The Nine Hour Pioneers: The Genesis of the Canadian Labour Movement

Paul Craven-Corporatism, Liberalism, and Mackenzie King

Veronica Strong-Boag-The Girl of the New Day: Canadian Working Women in the $1920 \mathrm{~s}$

Michael Piva-Militants without Power: The Toronto District Labour Council and Political Action, 1900-1921

David Frank and Nolan Reilly - The Emergence of the Canadian Socialist Movement in the Maritimes, 1899-1916

Plus documents, book reviews, and review articles.

Available, for $\$ 6.00$, through: G. Kealey

Labour/Le Travailleur

Department of History

Dalhousie University

Halifax, Nova Scotia

B3H 3J5

With a subscription, previous volumes can be ordered for $\$ 3.00$ each. 